\title{
The Perception On Public Sector Corruption (PSC) In Nigeria: An Insight From Experts In Anti-Corruption Agencies (ACA)
}

\author{
Naziru Suleiman \\ Lawan Yahaya ${ }^{2}$ \\ Magaji Abba ${ }^{3}$
}

\begin{abstract}
We have collected and analysed the perception of the experts from the two Nigerian notable anti-corruption agencies on PSC in Nigeria. Experts from the Independent Corrupt Practices Commission (ICPC) and the Economic and Financial Crimes Commission shared the experiences on how PSC in perceived in Nigeria. These experts are specialists and professionals in various fields of endevours. Furthermore, they are interacting with the phenomenon under investigations in in various capacity as investigators and prosecutors. Our initial aim was to gain an understanding from the perspectives of the corrupt public servants themselves. However, this proved difficult due to the secretive and complex nature of corruption. Even those found guilty of corruption and subsequently convicted, often deny the charges and hence decline speaking about it. Therefore, as the next plausible alternative, an insight from these experts was sought. Through qualitative research methodology paradigm, this study sourced data from face to face interviewes with these experts. The finding indicates the perception that PSC in Nigeria is a social reality which is a multifaceted phenomenon. It is being perceived differently depending on the lens through which it is being viewed. Therefore, any meaningful remedy to the menace of corruption in the country should commence at gaining an understanding of the perception held on corruption and appropriately addressing it.
\end{abstract}

\section{Introduction}

Many people presume the country "Nigeria", is synonymous to corruption and corrupt practices (Malgwi, 2004). As many cases of corrupt practices affecting the country or its citizens have drawn international attention. Corruption has been the greatest threat to the survival of the country as a nation state (Agbiboa, 2012). Though country is blessed with abundant natural resources and enormous human resources capital, yet remains largely underdeveloped (Ogbeidi, 2012).

The country on attainment of independence in 1960 was considered giant enough to lead Africa in socioeconomic revolution (Agbiboa, 2012; Atelhe \& Agada, 2014; Ogbeidi, 2012). However, it has now has turned out to be a cripple-giant (Imhonopi and Urim, 2013). This is consequential to corruption (Agbiboa, 2012; Osoba, 1996). It is evident in the literature, Nigeria's corruption is very devastating, pathetic and annoying (Agbiboa, 2012; Akpomi, Ugodulunwa, \& Nnadi, 2005; Osoba, 1996). Over the years, the federal government of Nigeria has been making several efforts by setting up many anti- corruption institutions such as the EFCC and ICPC to reduce cases of fraud and corruption. Still corruption persists as cases of corruption are continuously reported. Nigeria's rating on corruption by international anti-corruption bodies/organizations has portrayed Nigeria in a bad light. Its stands indicates high level of corruption as captured as earlier mentioned. Notable among these indices is the corruption perception index of the Transparency International (see (TI, 2013, 2014, 2015, 2016, 2017)).

Nigeria's case is special owing to the fact both the magnitude and the frequency of occurrence of the menace are very high (Agbiboa, 2012; Emeh \& Obi, 2013; Gbegi \& Okoye, 2013; Modugu \& Anyaduba, 2013). Corrupt practices among Nigerians are major challenges facing the development of the country (Olajide, 2014). For example, the Nigeria's ranking over the years on the corruption perception index of the Transparency International is not encouraging at all. Similarly, huge corruption cases are being recorded regularly in the country, thus indicating the intensity of the phenomenon (Agbiboa, 2012; Atelhe \& Agada, 2014). Corruption has been often cited as the only reason for change of governments in Nigeria since independence (Agbiboa, 2012; Osoba, 1996). 
In fact, the 2015's concluded general elections held on 28 march, 2015 has vindicated this position, whereby the issues of corruptions to a large extent appeared to have dominated the campaigns of the two major political parties (EFCC, 2015). Subsequently, the then ruling party was voted out of power because of corruption (Fafawora, 2015).

Corruption has been the bane of Nigeria's underdevelopment for decades, a common reason advanced for military incursion into the governmental affair of the country at some times since independence (Agbiboa, 2012). Nigerian case is so unique, in the sense that in spite of being among the top oil producers in world. In addition to being endowed with other natural and human resources, majority of Nigerians are living in abject poverty (Agbiboa, 2012; Malgwi, 2004).

Still, after winning the election, president Buhari has vindicated his stance on the fight against corruption. Daily Sun (2015) reports that Buhari widens up corruption war; orders the search light on the 36 former governors in Nigeria. Similarly, the Guardian (2015) reports that corruption is one of the three concerns of the new administration according to the president. Accordingly corruption must be destroyed before it destroys Nigeria (The Guardian, 2015).

In view of the forgoing, this paper seeks to understand the general perception on corruption from the perspective of the experts from the two Nigerian notable anti-corruption agencies on PSC in Nigeria. Experts from the Independent Corrupt Practices Commission (ICPC) and the Economic and Financial Crimes Commission shared the experiences on how PSC in perceived in Nigeria.

These experts are specialists and professionals in various fields of endevours. Furthermore, they have been interacting with the phenomenon under investigations in in various capacity as investigators and prosecutors of PSC. Our initial aim was to gain an understanding from the perspectives of the corrupt public servants themselves. However, this has proven difficult due to the secretive and complex nature of corruption so much so that even those found guilty of corruption and subsequently convicted, often deny the charges and hence decline speaking about it.

Therefore, as the next plausible alternative, an insight from these experts was sought. Through qualitative research methodology paradigm, this study sourced data from face to face interviews with these experts. To achieve this, the paper is structured into five sections. The first section, which is the current section covers the introduction while the next part is on reviewing literature on corruption. The third and the fourth sections cover the analyses and the discussions of the findings respectively, while the last section concludes the paper.

\section{Corruption in the Literature}

There is near consensus worldwide that corruption is a vice, an immoral act and an antithesis of progress and development. It's devastating effects have made it a very topical issue opens for discussion across the globe (Sadiq \& Abdullahi, 2013) and that it hurts everyone (Berlinski, 1997). Osoba (1996) opines that it is a form of global anti-social behavior which pervades every society depending on the nature and system of political inclination, legality and morality. It has been variously addressed; a cancer, a disease, a scourge (Neu, Everett, Rahaman, \& Martinez, 2013) a monster (Egwemi, 2012) a menace (Agbiboa, 2012) among the many connotations associated with the concept.

Just as there is diversity in the human race and culture, so is the meaning of the concept of corruption has been construed from divergent perspectives and orientations. As Egwemi (2012) posits corruption is a universal phenomenon having no regards for ethnic background, race creed or even geographical location. Furthermore, corruption is not new to human history as early civilizations had records of corruption and corrupt practices reported (Wells \& Hymes, 2012).

Thus, societal interaction and the history of civilizations are inseparable with corruption ever since the dawn of civilizations. Wells and Hymes (2012) posit that even the civilization that provided the basis for the modern day democracy had on so many occasions been afflicted by the menace of corruption. It is therefore very obvious that the concept of corruption is universal with historical antecedent (Agbiboa, 2012) which becomes much more pronounced and devastating in our modern day societies (Sadiq \& Abdullahi, 2013) due to the increase in the magnitude, frequency and the extent to which it is being perpetuated. No wonder the concept is now a subject of a multi-disciplinary and inter-disciplinary discourse and a topical issue interested by academics, governments, private bodies as well as other non-governmental organizations.

However, in spite of the universal nature and perversity of corruption, the intensity and the frequency with which it is carried out differed tremendously among societies or more precisely from country to country. Nye (1967) notes that even the most developed western societies are not free from corruption, but the developing nations are most hit by the menace. Interestingly some countries presently have been tagged as corruption ridden while others as less corrupt nations.

Sadiq and Abdullahi (2013) observe that while serious countries are committed towards addressing the scourge, others directly or indirectly go on encouraging it, so much so that it has developed into a critical state thus defying solution. 
This distinction is made along the divide line of the developed, developing and the under developed nations. Developed nations are seen as less corrupt because proper structures and controls to check corruption are to a large normally readily available (Nye, 1967).

Conversely the developing countries are labeled as corrupt and in some cases very corrupt (Agbiboa, 2012; Malgwi, 2004; Obuah, 2010; Ogbeidi, 2012). For example, Africa is considered the hub of corruption as cases of corruption are recorded on daily basis on one hand and bad leadership on the other (Agbiboa, 2012). He further contends that Africa's political history reveals that Africa is afflicted with bad leaders causing undue hardship on their people consequent of corruption.

\section{The Anti-Corruption Efforts in Nigeria}

The increasingly devastating effects of corruption had compelled the various successive governments in Nigeria to confront this strong headed monster by establishing some agencies and mechanisms to function as anti-corruption crusaders. According to Inokoba and Ibegu (2011) beginning with the General Murtala administration in 1976, the regime saw the establishment of the public complaint commission as an anticorruption body to check the excesses of public servants in the discharge of their statutory responsibilities. Equally, there were probe panels to investigate cases of malpractices and abuse of office especially during the preceding regime.

Similarly, there was the ethical revolution established during the reign of Alhaji Shehu Shagari to reorient Nigerians so as to imbibe high moral and ethical standards and shun the menace of corruption. The Buhari/Idiagbon regime came up with the war against the two evils of indiscipline and corruption (Inokoba \& Ibegu, 2011). Concurring with the above submission and at the same time adding more weight to it, Ibietan (2013) observes; still on the need on stamping out corruption completely from the affairs of the country, various governments at different times have been introducing bodies seem to checkmate the menace. For instance, criminal code (sections 98-115), the penal code, corrupt practices decree of 1976, ethical revolution of president Shehu Shagari, war against indiscipline by Buhari/Idiagbon regime, the ethical versus social mobilization by the Babangida's regime and the Nigerian Police Force's special fraud unit. Others cover legislative Acts as well as other functional schemes which include; Banks and other Financial Institutions Act of 1991, Financial malpractices in Banks Act of 1994, Advance Fee Fraud and Other Related Offences Act of 1995, the Independent Corrupt Practices Commission Act of 2000, the Economic and Financial Crimes Act of 2002 and then the Budget Monitoring and Price Intelligent Unit (BMPIU) also known as the Due Process Mechanisms (Ibietan, 2013).

Thus, the history of corruption in Nigeria is synonymous with anti-corruption efforts to counter the menace. Unfortunately, the menace seems to defy all forms of attempts to stamping it out from the country. One often wonders why this is so and what actually might have gone wrong in the fight against corruption? Again, the literature provides us with the answer.

Agbiboa (2012) posits, anti-corruption bodies established by government were poised to different postures at reform. He further observes there were those that were genuinely set up to earnestly address the scourge of corruption but along line the leaders got frustrated, perhaps due to the complexities of the phenomenon. Conversely, other leaders just double stand claiming to address the corruption problem vis-à-vis setting up anti-corruption bodies while in the actual sense they are not committed to that ordeal. Most importantly, as Azeez (2011) observes, in those situation the anti-corruption agencies are prevented from carrying out their assignments. Funny enough these leaders are in themselves culprit of corruption (Agbiboa, 2012). Pathetically, according to Inokoba and Ibegu (2011) the scourge of corruption has gone to the extent of swallowing some of the officials and agencies determined to fight it.

To sum it up Agbiboa (2012) posits, the many anti-corruption efforts have failed to accomplish their stated objectives consequent of the absence of strong commitment from the government. In the first instance, we see the incidences of investigations on corruption carried out which are never accompanied by any serious prosecution. Secondly, this is caused by the instability and inconsistency of government policies and regulations across the regimes.

Government policies and regulations often change with the change in government and this seriously affects policy implementation as the system (Nigeria) does not ensure continuity of laudable programmes and policies. Other criticisms levied against the anti-corruption agencies as presented by Azeez (2011) include; weak and ineffective structures establishing the anti-corruption agencies, poor funding, selective; vindictive; lopsided; biased; one sided; meretricious and falsely fight against corruption. Thus, the campaign has been a counter-productive venture.

Most importantly, the campaign has been the presidential machinery particularly during the Obasanjo administration to deal with opposition and others who prove to be stumbling block to those in power to perpetrate corrupt practices (Azeez, 2011).

\section{Our Method}

Apparently, the preceding sections foreground the relevance, suitability and justification of the qualitative methodology in guiding the present study. Thus, the procedure for conducting qualitative research or more 
specifically the methodology employed in qualitative research is emerging, inductive and often shaped by the experience of the researcher in data collection and analysis (Creswell, 2013). The idea here is to inductively build up from the ground (the participants' perspective) instead of imposing the researcher's worldview on the participants.

Therefore, this study believes that rather finding out the number held on corruption, the understanding of the perception provides a better means of getting an insight of the phenomenon. Therefore, this study wants to uncover from the understanding and experiences of the participants how they construct their worlds, interpret their experiences and the meaning the attribute to their experience on the perception of public sector corruption in Nigeria by the anti-corruption experts.

By so doing, the study expects the entire process to be inductively postured, focusing on understanding and ultimately the end product of research producing rich and thick description (Merriam, 2009).

\section{Analysis}

Analysing qualitative data entails making sense of the data. The process is often a complex undertaking involving moving forth and backward among concrete pieces of data, abstract concepts, deductive and inductive reasoning and description as well as interpretation (Creswell, 2013; Guest, MacQueen, \& Namey, 2012; King \& Horrocks, 2010; Merriam, 2009; Richards, 2015; Saldana, 2009). Through this process of making sense of the data, the research questions are answered. Thus, qualitative research lays emphasis on the significance of context and in making senses of the data, the analysis must take cognizance of the experiences, understandings and interpretations of the participants' accounts (King \& Horrocks, 2010; Merriam, 2009). The emerging meanings, insights or the understandings from making sense of the data constitute the findings (Merriam, 2009).

\subsection{Our Role as Researchers}

A distinguishing feature of the qualitative research is the fact that the researcher is part of the data collection and analysis process. Hence, the researcher is considered as an integral part of the research and cannot be detached thereof (Othman, 2011). In this research the researchers functioned as the primary instrument of data collection and analysis in line with the tradition of the qualitative research methodology. The researchers (in particular, the first author) paid regular visit to anti-corruption agencies' office (the field) during the data collection process. The aim was gaining an insight on the experiences and understandings of the participants of the study.

However, utmost caution was exercised by the researchers during the visit and the data collection process. This is because the anti-corruption bodies in Nigeria operate more or less like a security outfit and there are many restrictions within the offices and the premises. Notwithstanding, as the primary instrument of data collection and analysis as stipulated within the social constructionism, the researchers insisted on a face to face interaction with the research participants. Through this interaction the researchers shared the participants' understanding and experiences on the perception on PSC in Nigeria. Fundamentally, these meanings that the participants socially constructed on their world is what the researcher in interpretivist paradigm seeks to explore which is in the direction of the epistemological assumption (Creswell, 2014; Merriam, 2009). The multiple realities emanating from the interpretation of the participants' worldview supports the ontological assumption of the qualitative research methodology.

\subsection{Choice of the Research Participants}

The identification of participants is among the major steps in the collection of qualitative data. Qualitative research seeks to uncover how participants make sense of their world. There is the need of relating the social world with what the research phenomenon seeks to shed light on (King \& Horrocks, 2010).

As such choosing the right participant for qualitative research is essentially pertinent for achieving the validity of the study. The participants to these study are purposefully selected from the two anti-corruption bodies in Nigeria (the ICPC and EFCC). These participants totalling twenty-four in number cover diverse fields of expertise ranging from forensic accountants, forensic analysts, criminal investigators and legal and prosecutors.

\subsection{Interpreting Our Data}

In this section, the study describes the understanding of the participants' perception on PSC in Nigeria. The general perception on PSC in Nigeria as indicated in the perspective of the participants is that PSC is real. The reality of the PSC in Nigeria is revealed in the views expressed on the perception PSC. In interpreting the data obtained on the perception of PSC, four themes emerged to explain the reality of corruption. The general awareness that corruption is ever present in Nigeria is one of the perceptions identified on PSC in Nigeria. Other themes that emerged from the analysis, are the multifaceted and destructive nature of PSC. Lastly, PSC is beneficial to the perpetrators as they engage in the nefarious act. Figure 1 visualizes the themes and the subthemes on the perception on PSC in Nigeria. 
The reality of PSC is interpreted in its public presence in Nigeria. The perspective of participants based on the nature of reality indicates the presence PSC in Nigeria. The data stipulates that there is intensity of corruption and that corruption now more or less appears to be a social norm in the country. Thus, the presence of PSC in Nigeria creates the general awareness among the public of its existence. Having been involved with the phenomenon, the participants' interpretation of this social reality indicates the public presence of corruption in Nigeria. The intensity of PSC in Nigeria has been identified in the institutionalization of the phenomenon in certain situations. Anti-corruption experts based on the social construction of their experiences equally believe that PSC is visible, prevalent, and thriving.

Analysis of the data revealed the presence of PSC, is in part attributable to it becoming an institutionalized system in Nigeria. In this sense, institutionalization of PSC means corrupt practices are becoming part of public service delivery in Nigeria. Impliedly, corruption is so much engrained within the public-sector service. Thus, the PSC is considered as an institution shaping the public-sector practices in Nigeria. Several experts (Participants 2,13, 15 and 24) argued that "corruption is deeply rooted in Nigeria" and the "public sector service is affected by corruption". Even though "PSC cannot be eradicated completely", it needs to be "checkmated". The institutionalization of PSC is very much stressed as is evidenced by the following submissions by the participants.

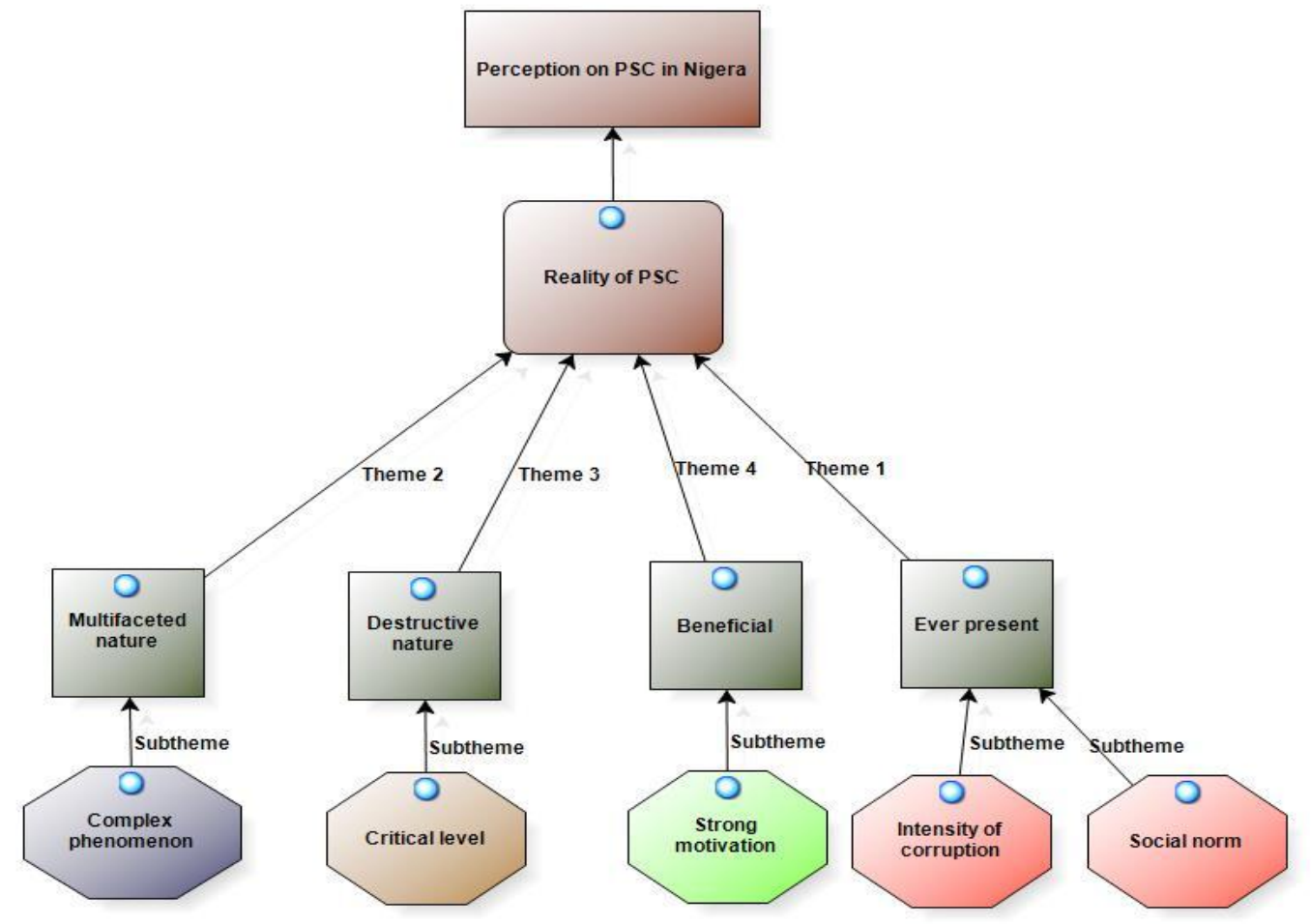

Figure-1. Theme and subthemes on the perception of PSC in Nigeria. Source: Developed by the researchers, findings (2018).

There is high index of corruption in Nigeria and particularly within the public-sector service practice. One participant stressed this position; "PSC accounts for the highest index of corruption in Nigeria" (Participant 1). The general views regarding the high incidence of PSC revolve around categories such as; "PSC is rampant", "there is huge corruption in Nigeria", PSC is largely practice", "there is much corruption in the public sector"

Comments made by participants concerning the high index of PSC include:

PSC in Nigeria is pervasive primarily considering where we are coming from. (Participant 3)

Much of the corruption in Nigeria is taking place in monetary terms (Participant 4)

There were a lot of corruption in the government ministries, department and agencies (Participant 9)

In further exploring the views of experts' perception on the reality of PSC, theme of multifaceted nature of corruption was developed. Ancillary analysis of the exploration indicates different forms and complex nature of corruption as a clandestine phenomenon. Figure 2 shows this theme, the subtheme and the categories linking the participants; interpretation of the reality. 


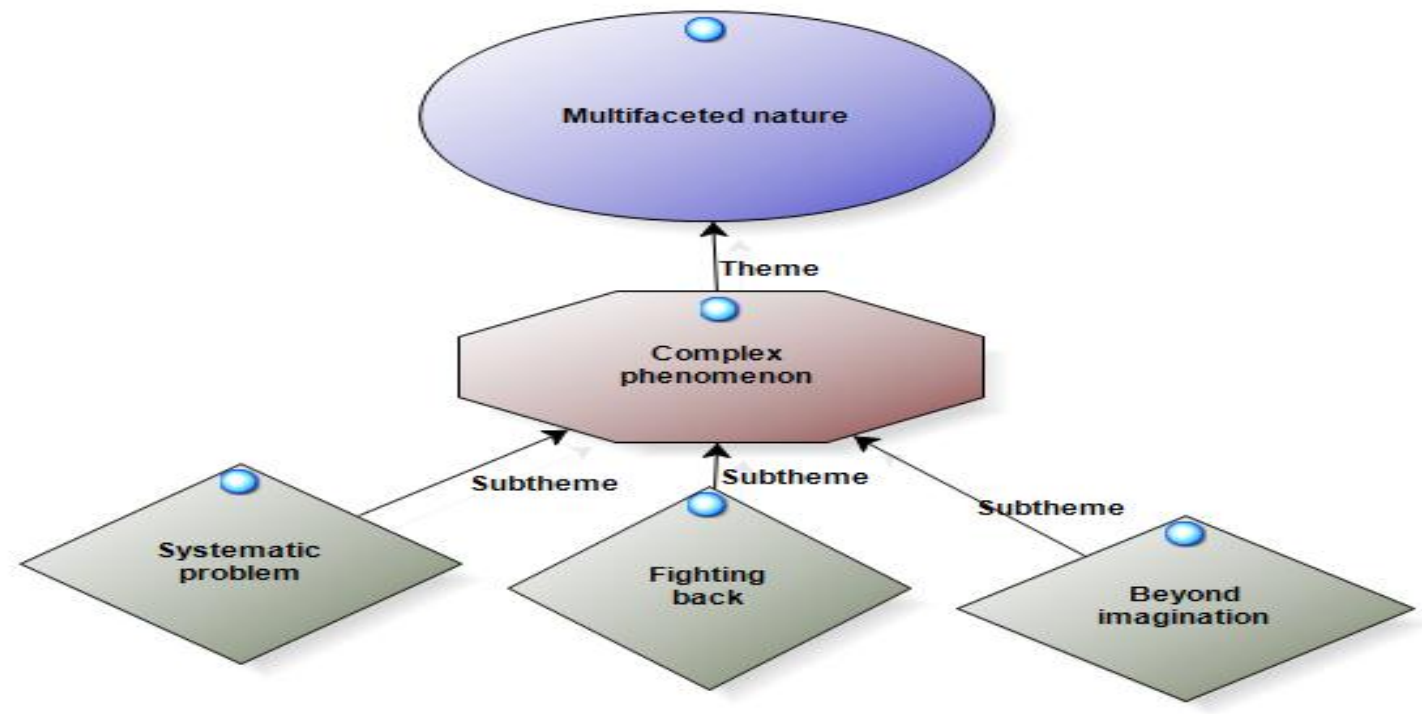

Figure-2. Multifaceted nature of corruption in Nigeria. Source: Developed by the researchers, findings (2018).

One common feature of corruption is its complexity which accounts for its multifaceted nature. A significant view established from the interpretation of the experts' worldviews relative to the complexity of corruption was the social construction that it is a systematic problem which fights back and beyond imagination.

The participants believe that as a complex phenomenon, corruption is a systematic problem in the Nigerian public sector service. It has become so ingrained in the system as so many cunning ways are being devised for beating the system. For example, Participant 4 perceives PSC to include other non-monetary aspects

...has persisted beyond the monetary aspects in terms of favouratism in a system.

This statement implies that the public-sector service in Nigeria has been penetrated so much to accommodate varieties of corrupt practices. Evidently captured in the voices of the participants, PSC presents a systematic problem to the performances of the public-sector service practices. Inferred from the analysis of the texts emerged from the understandings of participant 6 revealed the existence of a problem in the Nigerian public sector service.

There is problem within the public-sector system in Nigeria. (Participant 6)

He further identified the problem and the solution to the problem as he noted:

Corruption is a systematic problem which requires serious attention. (Participant 6)

However, other participants such as participant 8 have recognized certain indices that contributed to PSC becoming a systematic problem. He states, thus:

Hence, there is abuse of process and improper checks and balances. Internal control system is missing. Good internal control system entails segregation of duties within an organization. (Participant 8)

One of the complexities of corruption is that it is a crime the fights back. The participants perceive corruption as the only financial crime that bounces back on someone when it is being fought. Specifically, as it is evident in the voice of Participant 7 for example, corruption as envisaged through corrupt officers who are always ready for a big fight to keep on with the corrupt practices.

....but you should know that corruption is the only crime that fights back when you're fighting it and that corruption is like a cancer in the Nigerian system. (Participant 7)

Now, the biggest challenge is that even those who do not per take in it are afraid of the consequences of corruption fighting back. So, when they see it, they just pretend as if it doesn't happen or that it doesn't concern them. (Participant 22).

These views expressed on corruption fighting back have further complicated the already complex nature of corruption. It therefore follows that members of the public not in support of the bahaviour are in one way or the other compelled to condone it.

The complexity of PSC and of course, the multifaceted nature of the phenomenon is in fact the outcome of it defying one's imagination. The many forms and schemes being employed in the perpetration of PSC and other corrupt practices are such the one cannot easily imagine with precision. According to Participant 8, PSC in Nigeria has attained an unimaginable level in Nigeria and it is very disturbing and devastating.

The above conclusion that corruption is a complex phenomenon is one of themes (theme 2) developed in this study which explains the reality of PSC in Nigeria based on the perception of the participants. The next paragraph presents theme three of the study depicting the destructive nature of corruption. 
PSC in Nigerian has been identified in the data as destructive. The participants have stated that corruption has denied the country many of its God's giving potentials. The effects are very devastating as ordinary citizens cannot boast of enjoying the basic life amenities. The destructive nature of PSC has very much echoed in the submissions of the experts sharing their perception on the phenomenon. Deduced from their explanation, PSC has reached a critical level in Nigeria. Figure 3 visualizes this theme, the subtheme and the associated categories as indicated by the participants.

The reality of corruption as embedded in the destructive nature is such that it has reached a critical level as the interpretation of the data reveals. Participants believe that PSC in Nigeria has gone so bad and this was what prompted the setting up of the various anti-corruption agencies in the country. Stories abound indicating how terrible the situation is pertaining PSC. It has reached such a critical level that even the president of the federal republic of Nigeria commented; “if we don't kill corruption, corruption will kill us". Expressed in the views of the participants, PSC has reached a critical in the sense that it is alarming and has adverse effects. Further to this, PSC is associated with negative attributes.

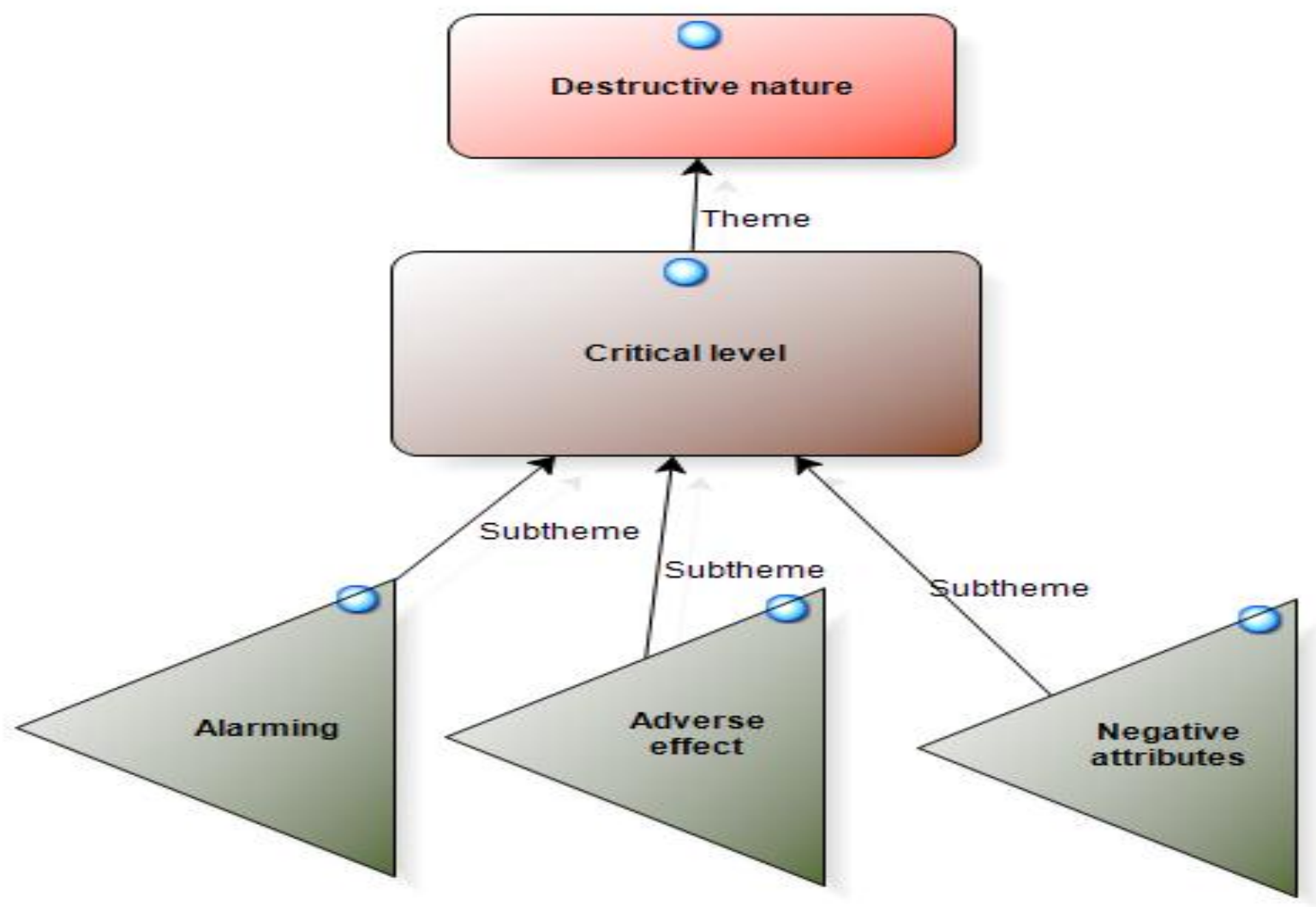

Figure-3. Theme three; corruption is destructive.

Source: Developed by the researchers, findings (2018).

Responses obtained from the participants' perspective have identified PSC as a cause for concern. The extent to which PSC has reached has been recognized as so serious and critical. Several voices indicate that PSC is "alarming", "a threat to the survival of Nigeria" and "requiring serious attention".

Corruption is a systematic problem which requires serious attention. (Participant 6)

It is beyond the imagination of everyone and has reached an alarming stage, very alarming indeed (Participant 2)

A significant view expressed relative to the critical level that PSC has assumed in Nigeria is its association with adverse effects. These effects as noted in the language of the participants cover descriptions such as "it is affecting the entire economy", "it is affecting everything" and "corruption is affecting the government". For example, evident in the voice of participant 1 who eloquently captured these multiple adverse effects of corruption. He submitted as follows:

It impacts negatively on development which includes human, development in infrastructure, public health system, educational system, energy supply and host of others.

In explaining corruption, negative attributes are used to describe it. Imminent from the voices of the participants, corruption is tagged as a "menace" "cancer", "evil" and a "monster". While several other used negative descriptors to indicate how they view the concept. The following are some of the descriptions 
identified: "corruption is terrible", "PSC is horrible" and repeatedly echoed in the responses is "corruption is endemic". For examples the following excerpts of the participant 7's point of view, vindicate this position:

...but you should know that corruption is the only crime that fights back when you're fighting it and that corruption is like a cancer in the Nigerian system. (Participant 7)

when a disease has into endemic, the doctors might not be enough to take care of them, you understand! So, no matter how well, effort was put by the doctors people would still see that they are not doing well, that they are not performing because it's so endemic and overwhelming. (Participant 7)

The above quotations, various perceptions of the participants highlighted the critical level reached by corruption which is interpreted under the theme embodying the destructive nature of corruption.

Furthermore, those who are involved in corruption and other corrupt practices in their own ways see the behaviour as beneficial to them. In their unique ways, they consider themselves deriving some benefits from the act. Even though not sanctioned by the state, this offers them the strong motivation to get indulge into corrupt activities as narrated by the experts. Figure 4 captures this theme and the subtheme as represented through the participants' narrations.

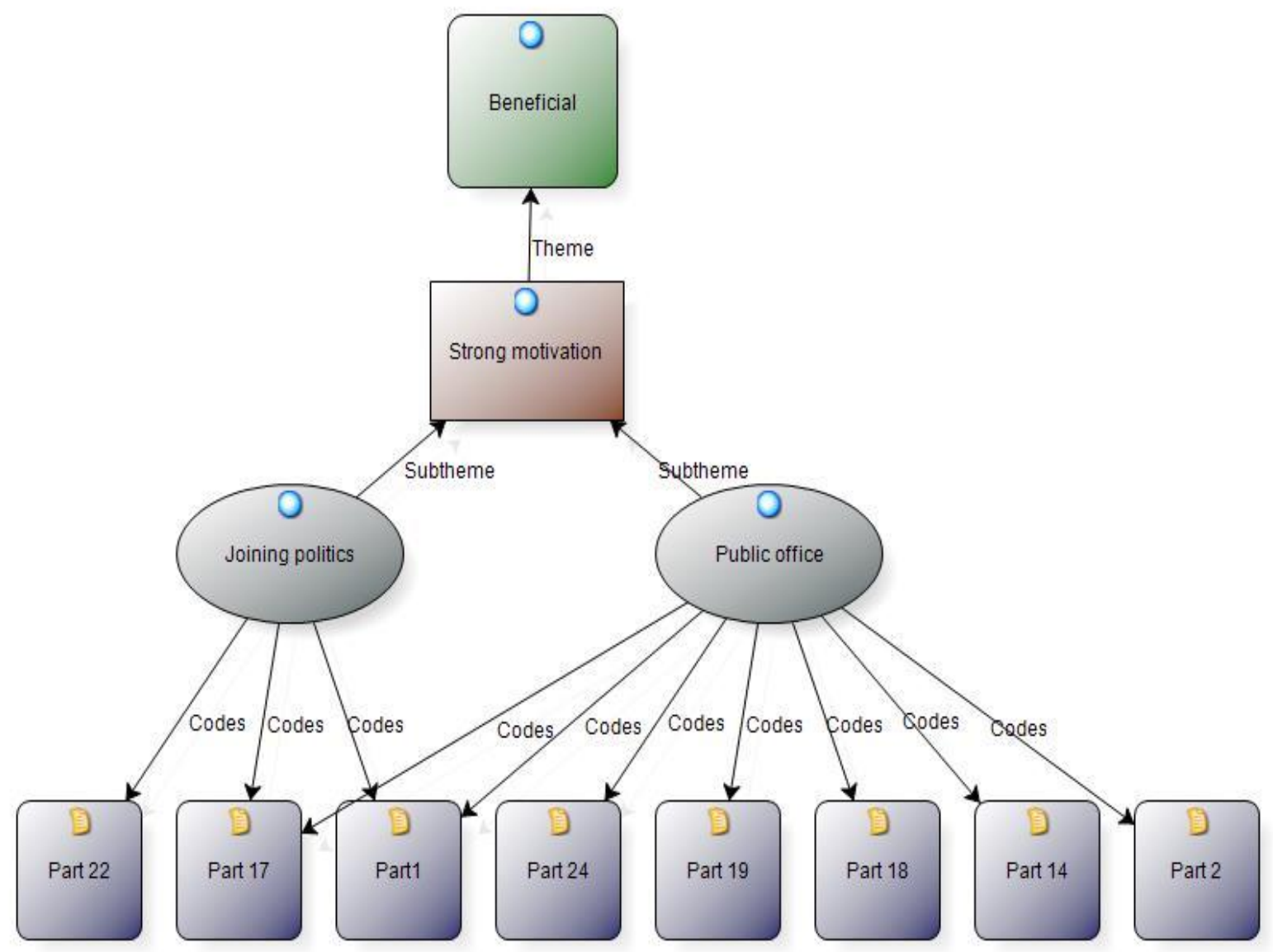

Figure-4. Corruption as beneficial.

Source: Developed by the researchers, findings (2018).

An aspect of corruption as established from the data obtained is deemed beneficial to the perpetrators and this offers them strong motivation to partake. The strong motivation is manifested in the motives behind joining politics and the use of public office to amass wealth. The next two sections cover these aspects from the interpretation of the social reality by the participants.

Data obtained from the participants' accounts indicate that politics in Nigeria is increasingly being regarded as a money-making venture due to presumed benefit accruing there from. Corrupt means of enriching oneself through politics is one of the views expressed on PSC in Nigeria.

PSC in Nigeria from my understanding it is an institutionalized system starting with the British colonial masters and as a result nobody sees it as a something, as a crime, as a bad system but people see it as going into the government. (Participant 13)

Engagement into public official responsibility based on the interpretation of the data obtained, provides the means to getting rich through corruption. Revelation from the participants suggest that securing public 
office is in some instances equated with getting rich. Therefore, as the first stage public office is greeted with a rosy welcome as means to an end. The end is of course, the proceeds of corruption that would emanate consequent of holding public office. In this regard, experts believe that public office is a strong motivation for PSC. Participant 17, opened up on this; thus, sharing her experiences and understanding:

I see it that, people see it if I get into that particular position, if I can, can hold this particular office that is the way of getting wealth, as is so easy. So, I see it as something that is so quite terrible that need to be dealt with as soon as possible, because it really affects Nigeria. (Participant 17)

The position above is further supported by the view expressed in Participant 19's account: ...use of office [inaudible], you see a lot of things like that. People using their position to confer advantage to either themselves or their family members (Participant 19).

\section{Discussion}

One of the held perception on the social reality of the Nigerian corruption as revealed in the findings, is its multifaceted nature. Multifaceted nature of corruption implies the different manifestations, multiple forms and dimensions that corruption assumes. Different means are devised to perpetrate corrupt practices in Nigeria such that it is often difficult to identify all the various forms it is being orchestrated. As pointed by the participants a lot of schemes are on the use to carry out the corrupt practices within the public service sector. Similar findings are noted in the literature on multifaceted nature of corruption (DeGraaf, 2007; DeGraaf \& Huberts, 2008; Egwemi, 2012; Inokoba \& Ibegu, 2011; Ogbeidi, 2012; Okogbule, 2006; Otusanya, 2011; Underkuffler, 2005). For example Okogbule (2006), documents that corruption is seen permeating every facet of the Nigerian national life thereby assuming such magnitudes causing the ranking of the country among the most corrupt nations for several years.

In the same vein, the findings of this study have further revealed that corruption being a complex phenomenon is a systemic problem in the Nigerian public sector which often fights back and it is beyond anyone's imagination. Corruption has been identified to be as imbued into the Nigerian public sector service as so many ways abound of defeating the system. The participants believe it to be systematic problem which has crossed the monetary boundary to non-monetary. Hence, it requires serious attention to be effectively tackled so as to salvage a country from its shackles. This finding is in line with the outcome of the study conducted by Agbiboa (2012) who posited that the complexity of the social and economic interactions that characterize the presence and reaching corruption has caused the difficulty of accepting easy treatment. Practices deemed corrupt can be pervasive, systematic and routine or they can be construed as trivial, petty and sporadic. Thus, it is such a diffuse and polyvalent phenomenon which makes it so complex to theorize. Another support for this study emanates in the finding from the study by Adebanwi and Obadare (2011) which reveals that Nigerian corruption is very systemic which does not just stop in threatening the nascent democracy the country is enjoying and retarding the economic growth. It has gone beyond making the attainment of the dividend of democracy and economic growth impossible to a full pledge banditry. Impliedly, the Nigerian case is not just simply siphoning the resource belonging to the state occurring at alarming rate to move to a situation whereby corruption is reorganizing forces to fight back.

The findings of this study also reveal the perception that corruption is destructive. It is destructive in the sense that it has robbed the country benefiting from many of its naturally endowed potentials. A country with enormous resources but whose majority of its citizens live in abject poverty consequent of corruption. The life expectancy of the citizens is abysmally below the global benchmark and the basic infrastructures are nearly absent. This finding has a wide support in the corruption literature, whereby many scholars are unanimous that corruption destroys the moral fabric and economic potentials of a country. For instance, Atelhe and Agada (2014) in a study conducted found that corruption causes complete distortion of public policies, poor governance, denies the citizens the basic necessities of life. Direct capital that would otherwise be invested is squandered mercilessly, misdirect budgetary allocations from the provisions of qualitative education, affordable health facilities and programmes and the basic social infrastructures. Obviously, all these portray the critical level that corruption assumes in Nigeria as identified in this study.

\section{Conclusion}

This study attempted to understand the perception of PSC in Nigeria from the perspective of Nigerian leading anti-corruption bodies (ICPC and EFCC). Using qualitative research methodology through face to face interviews with experts in the anti-corruption bodies, rich data was generated to explain the perception of PSC. The general perception of corruption, indicated the social reality of PSC in Nigeria. The analysis of the findings revealed this view on the social reality of PSC in the multifaceted nature, the destructive nature, beneficial aspect and the high presence of the phenomenon. The multifaceted nature of corruption is analysed within the context of the complexity of the phenomenon, while the destructive nature indicated the critical level it has assumed. The beneficial aspect offers the strong motivation for the perpetrators to commit such acts and finally, the presence of corruption is reflected in its intensity and its gradual assumption of a social norm in Nigeria. The implication of these findings is to assist in addressing the menace of PSC that has persistently affected the country since its independence in 1960. This understanding gained essentially, will 
foreground the government in its policy formulation toward reducing PSC in Nigeria. Future study may consider measuring these terms quantitatively. Also, the research participants may be expanded to include others knowledgeable agents in the anti-corruption such as the academics, non-governmental bodies and experts operating in private capacities.

\section{References}

Adebanwi, W., \& Obadare, E. (2011). When corruption fights back: Democracy and elite interest in Nigeria's anticorruption war. The Journal of Modern African Studies, 49(2), 185-213. Available at: https://doi.org/10.1017/So022278X11000012.

Agbiboa, D. E. (2012). Between corruption and development: The political economy of state robbery in Nigeria. Journal of Business Ethics, 108(3), 325-345. Available at: https://doi.org/10.1007/s 10551-011-1093-5.

Akpomi, M. E., Ugodulunwa, C. A., \& Nnadi, M. A. (2005). Strategies for fraud detection and minimization in Nigerian tertiary. Educational Institutions, 18(1), 55-61.

Atelhe, A. G., \& Agada, A. T. (2014). Re-visiting political corruption and development in Nigeria under democratic rule. Academic Journal of Interdisciplinary Studies, 3(1), 305-314. Available at: https://doi.org/10.5901/ajis.2014.v3n1p305.

Azeez, A. (2011). Endangering good governance for sustainable democracy: The continuing struggle against corruption in Nigeria. Jourrnal in Research, Peace, Gender and Development, 1(11), 307-314.

Berlinski, B. C. (1997). The dark figure of corruption. Policy Review, 155(July 2009), 71-82.

Creswell, J. W. (2013). Qualitative inquiry and reseach design: Choosing among five approaches. (L. Habib, K. Koscielak, B. Bauhaus, $\mathcal{E}^{\circ}$ M. Masson, Eds.) (3rd ed.). Los Angeles: Sage Publications, Inc.

Creswell, J. W. (2014). Educational research: Planning, conducting and evaluating quantitative and qualitatitive research (4th ed.). Harlow: Pearson Education Limited.

Daily Sun. (2015). Buhari widens up the fight against corruption, Daily Sun Nerespaper, (1) No 3229, p. 10.

DeGraaf, G. (2007). Causes of corruption: Towards a contextual theory of corruption. Public Administration Quarterly, 31(1), 39-86. Available at: https://doi.org/10.1007/s 13398-014-0173-7.2.

DeGraaf, G., \& Huberts, L. W. J. C. (2008). Portraying the nature of corruption using an explorative case study design. Public Administration Review, 68(4), 640-653. Available at: https://doi.org/10.1111/j.1540-62 10.2008.00904.x.

EFCC. (2015). Zero tolerance: The magazine of Nigeria's economic and financial crimes commission. Zero Tolerance: The Magazine of Nigeria's Economic and Financial Crimes Commission, 8(1 January-March), 54.

Egwemi, V. (2012). Corruption and corrupt practices in Nigeria: An agenda for taming the monster. Journal of Sustainable Development in Africa, 14(3), 72-85.

Emeh, Y., \& Obi, J. (2013). An empirical analysis of forensic accounting and financial fraud in Nigeria. African Journal of Social Sciences, 3(4), 112-121.

Fafawora, D. (2015). How really bad is public corruption in Nigeria. The Nation Newespaper, 1-3.

Gbegi, D., \& Okoye, E. I. (2013). Forensic accounting: A tool for fraud detection and prevention in the public sector. (A Study of Selected Ministries in Kogi State). International Journal of Academic Research in Business and Social Sciences, 3(3), 1-19.

Guest, G., MacQueen, K. M., \& Namey, E. E. (2012). Applied thematic analysis. (V. Knight, L. Habib, K. Koscielak, A. Virding, \& A. Rosenstein, Eds.). Los Angeles, New Delhi, London, Singapore, Washington DC: Sage Publications.

Ibietan, J. (2013). Corruption and public accountability in the Nigerian public sector: Interrogating the omission. European Journal of Business and Management, 5(15), 41-49.

Inokoba, P. K., \& Ibegu, W. T. (2011). Economic and financial crime commission (EFCC) and political corruption: Implication for the consolidation of democracy in Nigeria. Anthropologist, 13(4), 283-291.

King, N., \& Horrocks, C. (2010). Interviews in qualitatitive research (1 st ed.). Los Angeles, L: Sage Publications Limited.

Malgwi, C. A. (2004). Fraud as economic terrorism: The efficacy of the Nigerian economic and financial crimes commission. Journal of Financial Crime, 12(2), 144-164. Available at: https://doi.org/10.1108/13590790510624981.

Merriam, S. B. (2009). Qualitative research: A guide to design and implementation (2nd ed.). San Ffransisco: Jossey-Bass.

Modugu, K. P., \& Anyaduba, J. O. (2013). Forensic accounting and financial fraud in Nigeria: An empirical approach. International Journal of Business and Social Science, 4(7), 281-289.

Neu, D., Everett, J., Rahaman, A. S., \& Martinez, D. (2013). Accounting and networks of corruption. Accounting, Organizations and Society, 38(6-7), 505-524. Available at: https://doi.org/10.1016/j.aos.2012.01.003.

Nye, J. S. (1967). Corruption and political development : A cost-benefit analysis. American Political Science Association, 61(2), $417-427$.

Obuah, E. (2010). Combating corruption in a "failed" state: The Nigerian economic and financial crimes commission. Journal of Sustainable Development in Africa, 12(1), 27-53.

Ogbeidi, M. M. (2012). Political leadership and corruption in Nigeria since 1960 : A socio-economic analysis. Journal of Nigeria Studies, 1(2), 1-25.

Okogbule, N. S. (2006). An appraisal of the legal and institutional framework for combating corruption in Nigeria. Journal of Financial Crime, 13(1), 92-106.

Olajide, S. D. (2014). Forensic accounting technique: A means of successful eradication of corruption through fraud prevention, bribery prevention and embezzelement prevention in Nigeria. Kuwait Chapter of Arabian Journal of Business and Management Review, 4(1), 176-187.

Osoba, S. (1996). Corruption in Nigeria: Historical perspective. Review of African Political Economy, 23(69), 371-386.

Othman, Z. (2011). Integration of ethics in Malaysian corporate governance practices. 
Otusanya, O. J. (2011). Corruption as an obstacle to develpment in developng countries: A review of literature. Journal of Money Laundering Control, 14(4), 387-422.

Richards, L. (2015). Handling qualitative data a practical guide (3rd ed.). Los Angeles, New Delhi, London, Singapore, Washington DC.

Sadiq, M., \& Abdullahi, M. (2013). Corruption as the bane of Nigeria's development. International Journal of Economic Development Research and Investment, 4(1), 83-93.

Saldana, J. (2009). The coding manual for qualitative researchers (1st ed.). Los Angeles, New Delhi, London, Singapore, Washington DC: Sage Publications Limited.

TI. (2013). Corruption perceptions index 2013. Transparency International. Berlin.

TI. (2014). Corruption perceptions index 2014. Transparency International. Berlin.

TI. (2015). Corruption perception index 2015. Transparency International. Berlin.

TI. (2016). Corruption perception index 2016. Transparency International. Berlin.

TI. (2017). Corruption perception index 2017. Transparency International. Berlin.

Underkuffler, L. (2005). Captured by Evil: The Idea of Corruption in Law, 280, 1-51. Retrieved from http://papers.ssrn.com/abstract=820249\%5Cnhttp://papers.ssrn.com/sol3/papers.cfm?abstract_id=820249.

Wells, J. T., \& Hymes, L. (2012). Bribery and corruption case book. New Jersey: John Wiley and Sons Publishers. 